\title{
Analysis of Relevance between International HRM and Industry Demand: A Review of Scientific Literature
}

\author{
Lina Sukanti \\ Universitas Islam Syekh Yusuf, Indonesia \\ Email:lina.sukanti@unis.ac \\ Budi Harto \\ Universitas Pendidikan Indonesia, Indonesia \\ Corresponding author email: Email: budihartol@upi.edu \\ Panji Pramuditha \\ Universitas Pendidikan Indonesia, Indonesia \\ Email: panji.pramuditha@upi.edu
}

\begin{abstract}
This article attempts to analyze how the relevance of international human resource management and the demands of the world of work through an in-depth study of the evidence findings from the studies of global HR governance and employment experts. In short, we search the literature utilizing an online search. Our analysis involves coding, evaluating, interpreting systems under a phenomenological approach to obtain correct, valid, and reliable answers. So the results of our study can conclude that there is a relevance between international human resource management and the needs of the world of work between countries. The use of international-level human resources to achieve business targets without national borders is known as international human resource management. Thus this input is an addition to the parties involved in the world of international human resources management.
\end{abstract}

Keywords---HR management, international demand, in-depth literature analysis.

\section{Introduction}

Human resource (HR) governance is a critical study currently for several reasons (Armstrong \& Taylor, 2020; Hecklau et al., 2016). Because if the company wants to achieve business goals, they will not be able to quickly. In other words, they need the knowledge of HR governance, which will play a role in achieving the ultimate goals of their business operations through maximizing the individuals and employees they have (Kehoe \& Wright, 2013; Jiang et al., 2012). In order for business people to achieve this, there are many issues related to HR management. One of them is international human resources because human efforts globalize, environmental differences, cultural differences, convergence and divergence, and global employment. These are the concerns of this study where we want to see the relevance of HR governance and an international business context (Cooke et al., 2018; Dhir et al., 2020).

Pradiningrum et al. (2013) said that the impact of worker skill and inspiration on execution is hampered in the extent of global human asset the executives. The HRM work incorporates four exercises: procurement, improvement, inspiration, and support. Moreover, Schuler et al. (2002) said that worldwide human asset the board has gotten a genuine subject and has frequently drawn analysis due to the feebleness of instructive establishments to supply the HR required by global associations and organizations. Policymakers define global HR management as the influence between the three dimensions of HR activities, the type of employee, and the country in which it operates (Jiang et al., 2012; Boxall \& Purcell, 2011). Their findings have proven how human resource management affects the ultimate goals of every company and organization on a world level. The broad term in global HR management involves the 
same activities as domestic HRM. Sunarsi (2019) describes global HRM with three dimensions: extensive HR activities including labor procurement, allocation, and utilization. Three categories of employees in multinational companies: nationality of the host country, nationality of the parent country, and nationality of third countries (Irianto, 2011).

\section{International HRM}

Human resource management loss is often linked to business failure in an international setting. International Human Resource Management (HRM) is a concept that describes how HRM encompasses not just domestic but also global aspects (Yuniarsih \& Sugiharto, 2016). International HRM also influences the cultural aspects, types of employees, and national categories involved in international HRM activities. The author concludes that international HRM has more intricate complexity than domestic HRM (Triatmanto et al., 2019; Wahyuni et al., 2020).

They also believe that HR works for several international companies and says companies must continue learning a lot about the challenges faced by HR departments in the international business environment and how cultural factors can affect staff performance and well-being. The firm is often engaged in cross-cultural and comparative studies, with the aim of identifying and explaining cultural parallels and disparities. The research demonstrates how cultural disparities may have an effect on human rights policies. Mexican staff, for example, expect bosses to maintain their distance from them or to be formal (Sembiring, 2016). He also acknowledges that human resources have an effect on small and large enterprises' overall goals.

In Germany, employees cannot be a few minutes late and always have to formally call their positions. The factors used in HRM International are distinct from those used in a human resource production in other nations, which adds to the complexity (Arthur, 2013). The concept of human resource growth, both macro and micro, is a method of raising the expertise, abilities, and capacities of all community residents. Human resource development is the process of improving the quality of human capacity to achieve national achievement with development objectives that include planning and development (Okoye \& Ezejiofor, 2013). Micro human resources in development are planning education, training, and managing employees to achieve optimal results (Cooke \& Saini, 2010). This is a way to improve people's skills and knowledge to achieve national development goals. It is a way to increase people's knowledge and skills.

To put it another way, multinational human resource administration employs international talent to accomplish corporate objectives that have or have not yet gone global. Cross-cultural management, which examines human activity in institutions from a global viewpoint, is emphasized in foreign HRM. National HRM, in general, entails the same practices as domestic HRM. There are three approaches to foreign human resource management: multinational, geographic, and territorial (Bonache \& Festing, 2020).

\section{HR Safety}

Occupational protection and well-being are critical components of business operations. Any employee will perform to their full potential if their well-being is guaranteed. Occupational protection refers to a person's ability to operate healthily. The internal atmosphere refers to a person's capacity to care for himself, whereas the external environment refers to an external threat. Occupational safety and health, according to Willenbring (2005) refers to the medical, financial, and psychological conditions of the workers.

Occupational health and safety insurance is a primary concern across all types of cross-disciplinary practice. This is about ensuring the protection, fitness, and well-being of all who work in a workplace (Kamau, 2014). The occupational health and safety policy aims to ensure and establish a healthy and productive workplace. It will also shield coworkers, family members, employees, consumers, vendors, nearby neighborhoods, and other group members that are impacted by the working atmosphere as a side effect. Occupational nursing, occupational hygiene (or industry), environmental health, safety engineering, chemistry, and health physics are areas that could be involved (Sawe, 2013).

Companies that place a high priority on workplace protection and well-being calculate the costs of repeated strain accidents. Many businesses, such as insurance agencies, have been established to enhance environmental security, nuclear safety, government, and corporate responsibility. The main goal is to guarantee that disclosures regarding business or sector activities that are illegal or harmful to the community are entirely heard and that employees who sacrifice their careers to reveal errors are protected (Reese, 2018).

Since 1950, the organization and the World Health Organization also agreed to a common concept of occupational health. The Joint Committee on Occupational Health of the International Labour Organization and the 
World Health Organization approved it at its first session in 1950 and amended it at its twelfth session in 1995. "Occupational wellness shall strive to promote and maintain the maximum level of physical, emotional, and social well-being of employees," according to the concept. At all jobs; prevention among workers deviating from health due to their working conditions; protection of workers in their work from risks due to factors that are detrimental to health; placement and maintenance of workers in a work environment adapted to their physiological and psychological abilities; and, to summarize, job adaptations for man and each person for his work ". This standard depends on a system known as Plan-Do-Check-Act (Niu, 2010).

HR experts have wellbeing, security, and security duties in the association. This obligation incorporates recognizing risky conditions and practices, openness control and moderation methodologies, lawful consistency, advancement of a well-being society, and estimating the viability of wellbeing, security and security programs (Saraswat, 2020).

The word welfare and protection of security is an essential issue in any cross-disciplinary work. This is identified by securing the welfare, welfare, and government assistance of individuals involved with work in the work environment (Castles et al., 2012). The essence of the word welfare and security-related program is to ensure and build a protected and vital workplace. As an optional impact, this can also confirm colleagues, relatives, bosses, clients, providers, closest networks, and other local individuals affected by the working environment climate (Weiss, 2014). This may include relationships among various fields of study, including word-related medicine, word-related hygiene (or mechanical), general welfare, safety design, science, well-being physical sciences.

\section{Development of SDM}

Human resources are needed to support productivity and activities so that a company's goals can be achieved perfectly. The existing human resources can compete and keep up with the times, especially in globalization, where science and technology in various fields are developing rapidly. The selection process results will show the weaknesses or strengths of the individual in his competence; based on this, prospective employees will be given training and development.

HR management and world development as a shaping force with various aspects of HR operations: employee style, country of operation, and human resource management (Marchington et al., 2016). In general, international HR administration follows the same procedures as domestic HRM. The following is a quote from Story et al. (2014) about overcoming the challenges of global HRM viability: The board of international human resources is being consulted to comprehend further and establish authoritative multinational pioneers to meet the challenges of globalization. The development of a global mindset has a growing way of speaking but little research support. Any hypothesis-driven predecessors are recognized and observed in this inquiry. The article concludes with the potential implications of these findings for an influential global HR board.

Multinational company workers are divided into three groups: workers from host countries, workers from home countries, and workers from third countries. International HR Management explores human interactions in organizations from a global perspective and emphasizes cross-cultural management, cross-country management, language, and culture. This development aims to clarify, analyze, and compare international HR processes in several countries using comparative industrial relations and HR management literature (Brewster et al., 2016). Then try to focus on various aspects of human resource management in multinational organizations to prove more valuable.

\section{Compensation SDM}

Pay is something that workers get in return for their administration commitments to the organization. As indicated by Ruky, remuneration incorporates all costs brought about by the organization for laborers and appreciated by laborers. The level of pay must be responsive to the supply and demand of the labor market, as employers compete for the expected employees. In particular, Werther \& Davis (1996) describe the objectives of effective compensation management.

Every worker must expect compensation from the company that employs him in return for their work. Compensation can be in the form of money or provision of materials (objects) / facilities or better career opportunities (Kruse et al., 2019). The amount of compensation is influenced by several factors, including the size of the work and the type of work performed is; a sound compensation system will be able to benefit both parties, both for the employees themselves and the company. The relationship between the company and employees is mutually beneficial or commonly referred to as a Mutually Beneficial relationship (Van De Voorde et al., 2012). 
Here are some of the goals to be achieved from compensation: Get qualified employees according to company needs. Retaining existing employees. Respect Employee Performance, Productivity, and Loyalty. Guarantee of Justice. Controlling costs, especially on recruitment and training costs that arise when there is a change of staff. Meet government regulations (McDonnell \& Burgess, 2013).

International HR training is an aspect that occupies an important position so that the quality and capability of existing human resources can compete and keep up with the times (Keep \& Storey, 2014). In line with the current era of globalization, employee development methods must be adjusted and right on target to develop according to their needs. The selection process results will show the weaknesses or strengths of the individual in his competence; based on this, prospective employees will be given training and development.

\section{Training SDM International}

Pre-flight preparation is viewed as a fundamental advance in guaranteeing the viability and accomplishment of ostracizes abroad (Wurtz, 2014; Tihanyi \& Thomas, 2005). Social mindfulness preparation is prescribed to assist people with changing conditions and societies all the more rapidly. Ostracize workers should have the option to adjust and not feel confined from their nation of origin. An overall planned social mindfulness preparing project can be beneficial, as it looks to cultivate an enthusiasm for the host nation's way of life (Wurtz, 2014). It is imperative to note that such visits ought to apply to the places that global representatives are required to take and not just 'vacationer' encounters.

Training is defined as a planned effort by providing work learning facilities related to workers'/employees' knowledge, skills, and behavior of workers/employees (Brock et al., 2013; Cho et al., 2006). Development is concerned with how to acquire skills that can enhance and enhance their abilities. Employers everywhere see upgrading technical skills as the primary goal of training for employees. In-class training represents the bulk of training time in all countries and territories. The total number of employee training hours available per year varies from 26 hours in Asia to more than 49 hours in Europe. The number of training companies provide varies widely from country to country; the costs incurred on training per employee vary from $\$ 241$ in Asia (excluding Japan), \$ 359 in Japan, and \$ 724 in the US (Bloom \& Van Reenen, 2010). The objectives of training and development programs usually have more similarities than differences between countries, and the main reasons for providing training tend to be the same.

A Training Need Analysis (TNA) was created or what is called a Training Needs Analysis. Corporate HR managers worldwide must feel that local HR managers are a part of a more extensive overall so-called global corporate HR network. Researchers have found that companies are involved in some of the most influential HR systems development practices in the world (Sahoo \& Mishra, 2019). The most critical factor for achieving success is creating a worldwide custom infrastructure used to support, purchase, organize local activities to help better understand their systems and the challenges they face. The TNA contains the following matters: a new employee, new work equipment, a change in the bureaucratic management/administration system, and a new work quality standard.

The existence of employee rotation/relocation, increasing employees in facing new jobs and work situations. The critical point is to standardize what is assessed and be flexible in how it is assessed, according to the researchers conclude that. Treating local managers as equal partners is not complementary. Preparing is centered around improving the abilities and mastery of traditional HR. The objective to be accomplished from a preparation program is to improve individual execution in current positions or capacities (Askenazy \& Caroli, 2010; Turner et al., 2008).

\section{Enrolment SDM International}

HR is the main asset in an association or organization. Get a labor force that suits their necessities; an HRM cycle is required, which is called enrollment. Enrollment is the way toward discovering and drawing in qualified candidates to be chosen as workers as indicated by the necessary positions (Ekayanti \& Xiaoming, 2018; Napier, 1998). This enlistment cycle is done when there is a division that requires new representatives; it tends to be because representatives who have quit working or new openings should be done and require extra workers. Most ex-pats are enlisted inside instead of remotely, so the undertaking of convincing supervisors to prescribe and consent to deliver their best representatives for worldwide tasks stays a significant issue for global HR directors.

The best workers to fill vacant positions can be found in the sufficient context of qualifying preparation and competency candidates (Peterson et al., 2011; Schuler et al., 2011). This inner filling should be made possible by upgrading, reversing, or downgrading. Pivot or move is a position difference at the same level, whereas Demotion is 
a downgrade with two strategies for interior registration. The organization completes the occasional downgrade or downgrade. Outside registration is an organizational registration that comes from outside the organizational climate (Kang et al., 2011). The advantage of outside enrollment is that they can find individuals suitable for bringing in new thoughts and procedures. The drawbacks are that they can reduce the trust of existing representatives, reduce unity between new workers and old specialists, require costs for media promotion, testing and meetings, and expand preparation costs (Awe, 2012).

Registration is seeking and obtaining the possibility of workers in sufficient number and quality so that associations can select the most suitable individuals to handle job problems (Mabey \& Zhao, 2017). Many organizations should stand firm on the main foothold in central and auxiliary command, ethnocentric, polycentric, geocentric, and geocentric. Most ex-pats are registered internally and not remotely, so trying to convince supervisors to prescribe and agree to give their best workers for assignments around the world remains a significant problem for global HR heads (Gatewood et al., 2015; Schuler et al., 1993). The next cycle is how to select a candidate for a position until a prospective employee is selected as a representative to fill the required position.

Enlistment of workers to fill places that are as yet empty should be possible through two sources, specifically interior enrollment and outer enlistment. The upsides of interior enrollment are increment confidence, urge representative devotion to the organization, do not surge in dynamic and support self-advancement in workers. The shortcoming is the inadequate number of qualified individuals in the organization. Outside Recruitment is likewise required if an organization extends its business which makes the requirement for work increment. The extreme climate of the organization being referred to may come from organizations that give work, the overall population, instructive establishments, and government offices.

It can be challenging to find suitable employees for positions that require creative and innovative people for the positions that need to be filled. The open method, which announces vacant positions through internal company advertisements, is the best method for filling vacant positions in the internal recruitment process. The closed method asks managers to propose employees to be promoted or rotated, and the open method announces vacant jobs through company advertisements.

Human resource preparation entails determining when and how many workers each facility needs. Employees on the most influential overseas assignments were at least as likable and responsible. Workers should be prepared to adapt to the challenges that accompany living in another nation's general public, language, and customs. With regards to readiness and development, there are a couple of novel snags to consider: All specialists, paying little mind to their nation of beginning, should get fitting preparing and program advancement; and The organization must equip its employees with the skills and knowledge needed to succeed in a foreign country, and the motivation to succeed there and in the US for the long term. It is essential to consider factors such as the availability of qualified workers, adaptability, and adaptability to the country's culture and the language of the person working in the country, as well as the company's expectations. The best employees are willing and able to adapt to a foreign culture and work long hours and in long shifts, even if they are not used to doing so. They must be able to communicate effectively with other employees and have a strong desire to succeed.

Difference between HRM and International HRM. The distinction between the two is that the former has more roles and events. To work in a foreign context, the HR department must perform various tasks that may not be necessary for a domestic setting. According to the International HR Department, staff must consider accommodation, healthcare, and all other facets of the pay plan offered for overseas assignments. Foreign firms face an expensive challenge as expatriates refuse to return from international assignments on time. Another of these risks is terrorism, which is considered a significant concern for companies.

The HR department needs to commit to the host country and not just the country of origin. The organization wants to clearly show that the organization commits to the host nation, not just that country's business practices. The goal is to make the organization clearly show the organization that it wants to. It makes a decision that makes the organization a commitment to the country where the operation is based and that it is willing to work hard to benefit the country. It needs to show that it wants to make its employees a part of the organization's success.

Employees are employed by an organization headquartered in a third country. An employee is a citizen of one country who works in a second country. In particular, HR Management refers to activities used to utilize HR effectively, such as Recruitment, placement, and compensation. The challenging thing to do is to make the most out of an employee's time. MSDMI generally focuses on three main topics: Managing human resources in global companies, selecting employees, and managing existing human resources. The thing that is challenging about managing human resources globally is what can be run in a country. Managers must be able to manage human resources appropriately where human resources are appropriately where they are located. The economic system in 
each country has differences that affect differences in HRM. The cultural differences between countries are a challenge in itself and can affect the HRM of a company.

The HRM must create favorable conditions between workers and the cultural environment. The level of education between countries can vary, and the country's economic system can also affect differences between HRM and HRM in the country in which the company is operating. The number of employees in a company can be compared to the number of full-time employees. HRM can be different from a developing country to a developed country to an outside developing country and back to developing countries. The amount of time it takes to train an employee to learn a new skill can be similar to that of a child to learn how to read a novel. The ability to manage a human resource is similar to teaching a new skill set in a new language. The political system adopted by a country will affect HRM in manufacturing and application. HRM must adapt to the system of operation adopted by the country, which is the place of operation.

\section{Method}

Human resource development in any business context requires conformity with the demands of the job market. This study tries to analyze efforts to develop international human resources and the suitability of global needs and competition. For this reason, we have obtained a series of data from the Google scholar search engine from the 2010 to 2021 issue. To answer the questions of this study, we analyzed them by involving the coding system, in-depth evaluation, critical interpretation with a phenomenological approach so that our findings are valid and right on target. We depend on current data from the international journal literature that discusses current international HR issues. To make it easier for us to complete this task, we chose a descriptive-analytical study in study (Suharti \& Sugiarto, 2020; Wood et al., 2018).

\section{Results and Discussion}

Schuler et al. (2011) studied the worldwide ability of the board and worldwide ability challenges through Strategic freedoms for IHRM. The requirement for worldwide firms to be cutthroat in the worldwide commercial center has expanded drastically. For worldwide human asset, the board this has implied numerous essential chances. This possibility began to make in the last piece of the 1990s with the presence of "overall capacity the leaders" In this article, we portray these couple of overall capacity challenges and the real possibilities they present to firms. Likewise, a comparative report was done by Brewster et al. (2016) who saw that worldwide HRM straightforwardly interfaces with business needs.

The following studies were done by Caligiuri et al. (2020) see the COVID-19 pandemic HRM perspectives from around the world. We demonstrate the importance of enduring global business (IB) exploration and the need for additional work on global HR for executives. Multinational executives have tried a variety of strategies to mitigate the pandemic's impact. Most of the time, these practices revolve about keeping track of distance and reexamining boundaries. The pandemic has caused a widening of the cross-line gap and a widening of mental distance. We propose three fields for potential IHRM research: managing under duress, dealing with globally distributed and unexpectedly globally distributed jobs, reclassifying hierarchical execution, and working with virtual labor force output. We also have some insight into the benefits of a virtual labor force - a form of the labor force that could affect the 'fresh normal' of the post-COVID-19 environment. Ramirez et al. (2017) see worldwide HRM training as essential in today's business research on this special confessional.

Wood et al. (2018) investigated the extraordinary issue of the International Journal of Human Resource Management (IJHRM) on International Human Asset The Board in High-Vulnerability Environments. This critical issue plans to examine the worldwide human resource leaders' (IHRM) practices concerning high weaknesses considerably more intently. It searches for significant contexts such as monetary crises, financial authorizations, political and social vulnerability, natural disasters, and a severe decline. Organizations will face challenges adapting to such environments, where flightiness is prevalent, and vendor relationships, where time pressure will be added to the complex engagement. Organizations also benefit from genius independence in these situations. Governments and international organizations also infuse large sums of money into affected countries to aid in the recovery and modification process, siphoning off overall local requests and opening up fresh opportunities for MNEs in significant industries. In these conditions, the labor force is essential. MNEs' option value in entering a country under questionable circumstances can be substantial, particularly for aid organizations and between administrative offices, as well as global relief organizations. 
Björkman \& Welch (2015) outlining the field of global human assets the board research. This article presents a general structure of the worldwide human asset in the executive's field. The system has four distinct levels: Macro (including nations, areas, and enterprises), the Multinational Corporation, Unit, Individual and Individual. At each level, we differentiate between Influencing Factors, the HRM Function, and Proximal Outcomes.

Delbridge et al. (2011) proved that past the endeavor by broadening the skylines of International HRM. Worldwide HRM exploration will profit from an all-inclusive examination plan that moves past managerialism and past universalism. This will require a more extensive scope of speculative assets to be brought to bear. The article considers the chances for drawing on hypothetical systems from general examination zones.

Shen (2011) wants to know how they came up with a socially conscious global human asset commission concept. This paper introduces the concept of socially responsible IHRM (SRIHRM) and expands its growth in critical IHRM capacities by combining writing on global human resource management (IHRM) with corporate social responsibility. This paper also looks at the complexities of executing SRIHRM rehearsals and the factors that may influence global endeavors' decisions. Roads for further investigation and discussion of the commonsense implications are suggested.

The following is a quote from Story et al. (2014) about overcoming the challenges of global HRM viability: The board of international human resources is being consulted to comprehend further and establish authoritative multinational pioneers to meet the challenges of globalization. The development of a global mindset has a growing way of speaking but little research support. Any hypothesis-driven predecessors are recognized and observed in this inquiry. The article concludes with the potential implications of these findings for an influential global HR board.

Mahadevan (2020) studied the ethnographic examinations in global human asset the board: Following its unique anthropological importance, ethnography is perceived as a multi-paradigmatic attitude including five interrelated strands. Primary functionalist ethnography empowers profound examinations. Interpretive ethnography reveals insight into the objective secret factors of International Human Resource Management. Basic, postmodern, and postcolonial ethnography uncover the force imbalances related to different systems, practices, and work encounters in a worldwide setting. They can help defeat the characteristic force inequalities of International human asset executives. It is anything but a guide for ethnography, yet a guide empowering future International Human. Asset Management analysts intentionally, reflexively pick their ethnographic exploration procedure and. their exploration interest requests.

Chung et al. (2014) researched how South Korean MNEs' worldwide HRM approach: Hybridization of worldwide norms and nearby practices. Investigation of nine significant Korean MNEs' ways to deal with auxiliary HRM. Firms seek hybridization through the mixing of restrictions and worldwide normalization. Neighborhood tact is permitted if not counter to worldwide HRM framework necessities and "worldwide prescribed procedures" This essential direction gives off an impression of being necessary for a conscious reaction to the "liabilities of the beginning".

The last finding from Chung et al. (2014) on the conceptualization of worldwide joining and nearby responsiveness in International HRM Research was essential. This paper surveys how the ideas of worldwide incorporation and nearby reaction have been conceptualized in the global business and worldwide HRM writing. The observational examination is expected to address the exploration issues recognized through a comprehensive audit of writing. The paper infers that HRM rehearses by corporate and auxiliary HR entertainers in MNEs can incorporate into the HR field by their auxiliary organizations.

\section{Conclusion}

This section presents the conclusions of our review of several international HR management papers and their relation to field requests. So with the presentation of the findings and discussion, we can conclude, among other things, that International Human Resource Management is an effort to utilize global resources so that businesses and organizations can achieve the ultimate goal of profit and sustainability without looking at geographical, language, cultural and socio-economic boundaries. The position of the state or nation involved in the study of international HRM studies is indeed very relevant to the job market demands in various business contexts

\section{Acknowledgments}

Our paper would be useless without the support of our university colleagues and mentors, as well as funding from the Ministry of Research and Technology. On that basis, we thank you for all the assistance above, from the beginning to the completion of this study, and with all the input and reviews, we would like again to thank you for our article, Relevance Analysis. International HRM and Industry Demand: Scientific Literature Review completed on time. 


\section{References}

Armstrong, M., \& Taylor, S. (2020). Armstrong's handbook of human resource management practice.

Arthur, W. B. (2013). Complexity economics. Complexity and the Economy.

Askenazy, P., \& Caroli, E. (2010). Innovative work practices, information technologies, and working conditions: Evidence for France. Industrial Relations: A Journal of Economy and Society, 49(4), 544-565.

Awe, S. C. (2012). The entrepreneur's information sourcebook: Charting the path to small business success. ABCCLIO.

Björkman, I., \& Welch, D. (2015). Framing the field of international human resource management research. The International Journal of Human Resource Management, 26(2), 136-150.

Bloom, N., \& Van Reenen, J. (2010). Why do management practices differ across firms and countries? Journal of Economic Perspectives, 24(1), 203-224.

Bonache, J., \& Festing, M. (2020). Research paradigms in international human resource management: An epistemological systematisation of the field. SAGE Publications Sage UK: London, England.

Boxall, P., \& Purcell, J. (2011). Strategy and human resource management. Macmillan International Higher Education.

Brewster, C., Houldsworth, E., Sparrow, P., \& Vernon, G. (2016). International human resource management. Kogan Page Publishers.

Brock, D., Abu-Rish, E., Chiu, C.-R., Hammer, D., Wilson, S., Vorvick, L., Blondon, K., Schaad, D., Liner, D., \& Zierler, B. (2013). Republished: Interprofessional education in team communication: working together to improve patient safety. Postgraduate Medical Journal, 89(1057), 642-651.

Caligiuri, P., De Cieri, H., Minbaeva, D., Verbeke, A., \& Zimmermann, A. (2020). International HRM insights for navigating the COVID-19 pandemic: Implications for future research and practice. Springer.

Castles, F. G., Leibfried, S., Lewis, J., Obinger, H., \& Pierson, C. (2012). The Oxford handbook of the welfare state. OUP Oxford.

Chung, C., Sparrow, P., \& Bozkurt, Ö. (2014). South Korean MNEs' international HRM approach: Hybridization of global standards and local practices. Journal of World Business, 49(4), 549-559.

Cho, S., Woods, R. H., Jang, S. S., \& Erdem, M. (2006). Measuring the impact of human resource management practices on hospitality firms' performances. International Journal of Hospitality Management, 25(2), 262-277. https://doi.org/10.1016/j.ijhm.2005.04.001

Cooke, F. L., \& Saini, D. S. (2010). (How) Does the HR strategy support an innovation oriented business strategy? An investigation of institutional context and organizational practices in Indian firms. Human Resource Management: Published in Cooperation with the School of Business Administration, The University of Michigan and in Alliance with the Society of Human Resources Management, 49(3), 377-400.

Cooke, F. L., Wu, G., Zhou, J., Zhong, C., \& Wang, J. (2018). Acquiring global footprints: Internationalization strategy of Chinese multinational enterprises and human resource implications. Journal of Business Research, 93, $184-201$.

Delbridge, R., Hauptmeier, M., \& Sengupta, S. (2011). Beyond the enterprise: Broadening the horizons of International HRM. Human Relations, 64(4), 483-505.

Dhir, S., Ongsakul, V., Ahmed, Z. U., \& Rajan, R. (2020). Integration of knowledge and enhancing competitiveness: A case of acquisition of Zain by Bharti Airtel. Journal of Business Research, 119, 674-684.

Ekayanti, M., \& Xiaoming, H. (2018). Journalism and political affiliation of the media: Influence of ownership on Indonesian newspapers. Journalism, 19(9-10), 1326-1343.

Gatewood, R., Feild, H. S., \& Barrick, M. (2015). Human resource selection. Cengage Learning.

Hecklau, F., Galeitzke, M., Flachs, S., \& Kohl, H. (2016). Holistic approach for human resource management in Industry 4.0. Procedia Cirp, 54, 1-6.

Irianto, J. (2011). Manajemen sumber daya manusia sektor publik di Indonesia: Pengantar pengembangan model MSDM sektor publik. Jurnal Masyarakat, Kebudayaan Dan Politik, 24(4), 281-291.

Jiang, K., Lepak, D. P., Hu, J., \& Baer, J. C. (2012). How does human resource management influence organizational outcomes? A meta-analytic investigation of mediating mechanisms. Academy of Management Journal, 55(6), 1264-1294.

Kamau, E. N. (2014). Enforcement and compliance on occupational health and safety measures in industries in Thika municipality, Kiambu county. Bachelors Degree in Environmental Planning and Management Research Project, Department of Planning and Management, School of Environmental Studies, Kenyatta University. 
Kang, D., Stewart, J., \& Kim, H. (2011). The effects of perceived external prestige, ethical organizational climate, and leader-member exchange (LMX) quality on employees' commitments and their subsequent attitudes. Personnel Review.

Keep, E., \& Storey, J. (2014). Corporate training strategies: The vital component? New Perspectives, 109-125.

Kehoe, R. R., \& Wright, P. M. (2013). The impact of high-performance human resource practices on employees' attitudes and behaviors. Journal of Management, 39(2), 366-391.

Kruse, D. L., Freeman, R. B., \& Blasi, J. R. (2019). Shared capitalism at work: Employee ownership, profit and gain sharing, and broad-based stock options. University of Chicago Press.

Mabey, C., \& Zhao, S. (2017). Managing five paradoxes of knowledge exchange in networked organizations: New priorities for HRM? Human Resource Management Journal, 27(1), 39-57.

Mahadevan, J. (2020). Ethnographic studies in international human resource management: Types and usefulness. German Journal of Human Resource Management, 34(2), 228-251.

Marchington, M., Wilkinson, A., Donnelly, R., \& Kynighou, A. (2016). Human resource management at work. Kogan Page Publishers.

McDonnell, A., \& Burgess, J. (2013). The impact of the global financial crisis on managing employees. International Journal of Manpower.

Napier, N. K. (1998). International human resource management in developing and transitional economy countries: A breed apart?. Human Resource Management Review, 8(1), 39-77. https://doi.org/10.1016/S10534822(99)80039-4

Niu, S. (2010). Ergonomics and occupational safety and health: An ILO perspective. Applied Ergonomics, 41(6), 744-753.

Okoye, P. V., \& Ezejiofor, R. A. (2013). The effect of human resources development on organizational productivity. International Journal of Academic Research in Business and Social Sciences, 3(10), 250.

Peterson, C., Park, N., \& Castro, C. A. (2011). Assessment for the US army comprehensive soldier fitness program: The global assessment tool. American Psychologist, 66(1), 10.

Pradiningrum, E. R., Larasati, H., \& Santoso, S. (2013). Pengaruh kompetensi dan motivasi pegawai terhadap kinerja pegawai sekretariat DPRD kota Semarang. Journal of Public Policy and Management Review, 2(3), 84-94.

Ramirez, J. A., Wiemken, T. L., Peyrani, P., Arnold, F. W., Kelley, R., Mattingly, W. A., Nakamatsu, R., Pena, S., Guinn, B. E., \& Furmanek, S. P. (2017). Adults hospitalized with pneumonia in the United States: Incidence, epidemiology, and mortality. Clinical Infectious Diseases, 65(11), 1806-1812.

Reese, C. D. (2018). Occupational health and safety management: A practical approach. CRC press.

Sahoo, M., \& Mishra, S. (2019). Effects of trainee characteristics, training attitudes and training need analysis on motivation to transfer training. Management Research Review.

Saraswat, P. (2020). A Study on Occupational Health Psychology of Employees in IT Sector in Ahmedabad City. Medico Legal Update, 20(3), 313-319.

Sawe, M. J. (2013). Effects of occupational health and safety practices on employees' productivity in Mumias Sugar Company, Kenya [PhD Thesis]. Moi University.

Schuler, R. S., Budhwar, P. S., \& Florkowski, G. W. (2002). International human resource management: Review and critique. International Journal of Management Reviews, 4(1), 41-70.

Schuler, R. S., Dowling, P. J., \& De Cieri, H. (1993). An integrative framework of strategic international human resource management. Journal of management, 19(2), 419-459. https://doi.org/10.1016/0149-2063(93)90059-V

Schuler, R. S., Jackson, S. E., \& Tarique, I. (2011). Global talent management and global talent challenges: Strategic opportunities for IHRM. Journal of world business, 46(4), 506-516. https://doi.org/10.1016/j.jwb.2010.10.011

Sembiring, R. (2016). Impact of human resources' knowledge and skills on SMEs' in Medan City, Indonesia. International Journal of Management, Economics and Social Sciences, 5(3).

Shen, J. (2011). Developing the concept of socially responsible international human resource management. The International Journal of Human Resource Management, 22(06), 1351-1363.

Story, J. S., Barbuto Jr, J. E., Luthans, F., \& Bovaird, J. A. (2014). Meeting the challenges of effective international HRM: Analysis of the antecedents of global mindset. Human Resource Management, 53(1), 131-155.

Suharti, L., \& Sugiarto, A. (2020). A qualitative study OF Green HRM practices and their benefits in the organization: An Indonesian company experience. Business: Theory and Practice, 21(1), 200-211.

Sunarsi, D. (2019). Penerapan MSDM Strategis Dalam Upaya Meningkatkan Kemampuan Organisasi dalam menyongsong Revolusi 4.0. Jurnal Ilmiah MEA (Manajemen, Ekonomi, \& Akuntansi), 3(1), 221-233. 
Tihanyi, L., \& Thomas, W. B. (2005). Information-processing demands and the multinational enterprise: A comparison of foreign and domestic earnings estimates. Journal of Business Research, 58(3), 285-292. https://doi.org/10.1016/S0148-2963(03)00133-4

Turner, R., Huemann, M., \& Keegan, A. (2008). Human resource management in the project-oriented organization: Employee well-being and ethical treatment. International Journal of Project Management, 26(5), 577-585. https://doi.org/10.1016/j.ijproman.2008.05.005

Triatmanto, B., Wahyuni, N., \& Respati, H. (2019). Continual human resources empowerment through human capital and commitment for the organizational performance in hospitality industry. Quality Acses to Sucses, 20(173), 84-91.

Van De Voorde, K., Paauwe, J., \& Van Veldhoven, M. (2012). Employee well-being and the HRM-organizational performance relationship: A review of quantitative studies. International Journal of Management Reviews, 14(4), 391-407.

Wahyuni, N., Kulik, A. A., Lydia, E. L., Shankar, K., \& Huda, M. (2020). Developing Region to Reduce Economic Gap and to Support Large Environment Activities. Journal of Environmental Treatment Techniques, 8(1), 540545.

Weiss, J. W. (2014). Business ethics: A stakeholder and issues management approach. Berrett-Koehler Publishers.

Werther, W. B., \& Davis, K. (1996). Human Resource and. Personnel Management.

Willenbring, M. L. (2005). Integrating care for patients with infectious, psychiatric, and substance use disorders: Concepts and approaches. Aids, 19, S227-S237.

Wood, G., Cooke, F. L., Demirbag, M., \& Kwong, C. (2018). International Journal of Human Resource Management (IJHRM) Special Issue on: International human resource management in contexts of high uncertainties. Taylor \& Francis.

Wurtz, O. (2014). An empirical investigation of the effectiveness of pre-departure and in-country cross-cultural training. The International Journal of Human Resource Management, 25(14), 2088-2101.

Yuniarsih, T., \& Sugiharto, M. (2016). Human resource management model to create superior performance. International Journal of Education, 9(1), 75-81. 